\title{
POLICE DISCRETION AND DISCRIMINATORY ENFORCEMENT
}

JOSEPH H. TIEGER*

A numbers-runner is arrested for violation of a gambling statute while a high-stakes poker game at an upper-class gentlemen's club goes on unmolested. A man with one marijuana cigarette in his possession is arrested, not because he more than others should be imprisoned, but simply as an exemplary warning and deterrent to 30,000 other marijuana smokers in the city, and as a token law-andorder gesture for the rest of the population. A state trooper recognizes a drunk driver as the son of the president of the local bank and decides not to arrest him. A corps of building inspectors pore over a print shop where the local underground newspaper is produced and detect a violation of an obscure code provision that previously has seldom, if ever, been enforced. A policeman stops a long-haired youth who is playing a harmonica in the park and asks him for identification; when the youth appears arrogant, the policeman arrests him for disorderly conduct.

These examples depict the reality of law enforcement under our "government of laws, not men." The reality in the street is one of discriminatory and selective enforcement. The reality in the courtroom is not much better. Although the Supreme Court has stated repeatedly and unequivocally that discriminatory enforcement violates the equal protection clause of the fourteenth amendment, many state and lower federal courts blandly withhold constitutional protection of any sort. Indeed, Supreme Court doctrine itself imposes so heavy a burden of proof that the victim of discriminatory enforcement rarely finds vindication of his claim in the judicial forum.

The purpose of this article is not to condemn policemen. If it seeks to condemn anything, its target is the law enforcement system itself, and ultimately, of course, the society in general. The police misconduct involved in discriminatory enforcement is not a problem of stupid or brutal individuals and is not remediable by such solutions as higher pay for the police. ${ }^{\prime}$ It is structural, not aberrational, and is

* Member of the North Carolina Bar; A.B. 1963, J.D. 1970, Duke University.

1. But $f$. The AtLantic, March 1969 (Special Supplement: The Police and the Rest of Us). THE FOLLOWING HEREINAFTER CITATIONS ARE USED IN THIS ARTICLE:

H. Goldstein, Police Discretion: The Ideal Versus the Real, 23 PuB. AM. REv. 140 (1963) [hereinafter cited as H. Goldstein];

J. Goldstein, Police Discretion Not to Invoke the Criminal Process: Low-Visibility 
more nearly inevitable in our legal system than the conventional wisdom can comfortably concede. Vast discretion, which in practice is unreviewable, is knowingly conferred on individual policemen. ${ }^{2}$ The power to define what conduct shall be criminal is effectively delegated to the police, ${ }^{3}$ enabling them to "do on the domestic level what the armed forces do on the international level-protect the way of life of those in power."4

\section{The Conceptual FramewOrk}

Police are endowed by our criminal laws with the power to select from the universe of violators those persons who shall be subject to the criminal process. ${ }^{5}$ Given this reality, we are confronted with questions that challenge the very foundation of our judicial system: does the customary process by which some are chosen to be arrested subject certain classes to a penal process from which more favored classes are, to some extent, exempt? Do denials of due process and equal protection in that process make a sham of the protections accorded the arrestees once they are brought to trial? Does discriminatory enforcement make our criminal system simply another institution to oppress the disfavored?

The literature of discriminatory law enforcement is to be found less in the law journals than in the underground newspapers of the political left. ${ }^{6}$ For the poor, the Black, the culturally-deviant, and the

Decisions in the Administration of Justice, 69 YALE L.J. 543 (1969) [hereinafter cited as J. Goldstein];

LaFave, The Police and Nonenforcement of the Law (2 pts.), 1962 Wisc. L. REv. 104, 179 [hereinafter cited as LaFave];

Remington \& Rosenblum, The Criminal Law and the Legislative Process, 1960 U. ILL. L.F. 481 [hereinafter cited as Remington \& Rosenblum];

Comment, The Right to Non-discriminatory Enforcement of State Penal Laws, 61 Colum. L. REV. 1103 (1961) [hereinafter cited as The Right to Nondiscriminatory Enforcement].

2. See, e.g., Barrett, Police Practices and the Law-From Arrest to Release or Charge, 50 Calif. L. Rev. 11, 26-27 (1962); J. Goldstein; La Fave 119-21.

3. See, e.g., LaFave 122-25; Remington \& Rosenblum 494; Remington, The Law Relating to "On the Street" Detention, Questioning and Frisking of Suspected Persons and Police Arrest Privileges in General. 51 J. CrIM. L.C. \& P.S. 386, 394 (1960); Robinson, Police and Prosecutor Practices and Attitudes Relating to Interrogation as Revealed by Pre-and Post-Miranda Questionnaires: A Construct of Police Capacity 10 Comply, 1968 DUke L.J. 425, 502-05.

4. E. Cleaver, Soul oN ICE 129 (1968). For the statement that the police function is "to support and enforce the interests of the dominant political, social, and economic interests of the town, and only incidentally to enforce the law," see A. Niederhoffer. Behind the Shield 12 (1967).

5. See, e.g., Robinson. supra note 3, at 502-05.

.6. See virtually any edition of such papers as The Guardian (published weekly at 197 E. 4 th 
politically-activist minorities, constitutional protections are easily rendered meaningless by the capricious exercise of unreviewable discretion by the policeman on the beat, yet most legal scholars are too dazzled by each successive refinement of courtroom procedures to even notice. ${ }^{7}$

Conventional political theory indicates, of course, that our criminal law, like other laws in our society, are grounded in democratic processes. Laws prescribing rules by which the citizenry shall be governed are enacted by legislatures chosen by the people. The laws are enforced by the police, who perform a ministerial function-impartially seeking out violations and taking the violators into custody. In many jurisdictions the theory is articulated in statutory language imposing upon the police the duty to diligently and faithfully enforce all the penal laws. ${ }^{8}$ If the theory is a political fiction,

St., New York, N.Y.); The Great Speckled Bird (published weekly at P.O. Box 54495, Atlanta, Ga.); The Protean Radish (published weekly at Box 202, Chapel Hill, N.C.); The Southern Patriot (published monthly by the Southern Conference Educational Fund. at $3210 \mathrm{~W}$. Broadway, Louisville, Ky.).

7. Professor Davis offers the following metaphor:

Doing the research needed for a developing legal system may be compared with keeping in repair an old roof of an enormous building. Our scholarly roof in its present condition is strange to behold. Most of it at the rules end is extremely strong, but portions at the discretion end have rotted away, leaving big holes where the water rushes in and does great damage. Only an occasional worker gives attention to the big holes, while the majority of workers swarm over the rules end, stopping or preventing slow leaks, and reinforcing at points where leaks seem impossible. The reinforcements are both excessive and spotty. The roof is a hundred feet thick in some spots, but these are the very spots that attract still more workers. Not much is attempted except patchwork, and that is one reason the workers ignore the big holes, many of which call for structural changes requiring architectural imagination. K. DAvis, DisCRETIONARY JUSTICE vi-vii (1969).

8. See, e.g., Mich. Stat. ANN. $\$ 5.1752$ (1949), stating:

It shall be the duty of the police. . . under the direction of the mayor and chief of police, and in conformity with the ordinances of the city, and the laws of the state. . to pursue and arrest any person fleeing from justice . . to to apprehend any and all persons in the act of committing any offense against the laws of the state . . . and to take the offender forthwith before the proper court or magistrate, to be dealt with for the offense; to make complaints to the proper officers and magistrates of any person known or believed by them to be guilty of the violation of the ordinances of the city or the penal laws of the state; and at all times diligently and faithfully to enforce all such laws. . . .

Accord, e.g.. Mass. ANN. Laws ch. 41, § 98 (1952).

Most police manuals likewise speak in terms of ministerial duty. See J. Goldstein 557-58 nn. 26-27. But cf. L. Schwartz \& J. Goldstein, Police Guidance Manuals: A Phil.adelphia MODEL (1968). The continuing validity of the myth of full enforcement may be attributed in large measure to the police themselves who "find it easier to answer that they 'enforce the law' than answer that they must 'select those laws which are the most important, taking account of limited enforcement resources' [since] [t]he latter approach may raise legal issues as well as public relations problems." Remington \& Rosenblum 495 . See also H. Goldstein 144. 
then it is a legal fiction as well, for many courts have spoken of police enforcement as a compulsory ministerial act. ${ }^{9}$

Only recently have legal researchers taken issue with that official myth and initiated efforts to delineate the extent to which individual policemen exercise discretion in the process that leads one man into the courtroom as a criminal defendant and leaves another man untouched. ${ }^{10}$ It is axiomatic, of course, that our constitutional guarantees of due process and equal protection forbid legislative enactment of criminal laws that invidiously apply only to one class of persons. It is abundantly clear, however, that there are many situations in which the legislature gives the policeman the latitude to do precisely what the legislature is forbidden to do itself. This latitude is not based on an express statutory grant; on the contrary, statutes frequently purport to mandate full enforcement of all criminal laws." Nevertheless, existing side-by-side with these statutory mandates are other statutes which clearly do not contemplate full enforcement, statutes proscribing conduct which the legislature did not intend to be the subject of enforcement efforts. Such statutes permit the police to define the actual limits of criminal conduct. ${ }^{12}$ Furthermore, because police departments must allocate their detection and investigation resources, it is clear that they are not physically able to enforce all laws with the same intensity. ${ }^{13}$ It should be obvious that someone will

9. See Kadish, Legal Norm and Discretion in the Police and Sentencing Processes, 75 HARV. L. Rev. 904, 906 n.7 (1962).

10. See The Police: Six Sociological Essays (D. Bordua ed. 1967); P. Chevigny, Police Power: Police Abuses in New York City (1969); K. Davis, supra nole 7; W. lafave, Arrest: The Decision to Take a Suspect Into Custody (1965); J. Skolnick, Justice Without Trial: Law Enforcement in Democratic Society (1966); Barrell, supra note 2; Breitel, Controls in Criminal Law Enforcement, 27 U. CHI. L. Rev. 427 (1960); H. Goldstein, Police Policy Formulation: A Proposal for Improving Police Performance, 65 Micls. L. REv. 1123 (1967); H. Goldstein; J. Goldstein; Kadish, supra note 9; LaFave; LaFave \& Remington, Controlling the Police: The Judge's Role in Making and Reviewing Law Enforcement Decisions, 63 Mich. L. REv. 987 (1965); Reich, Police Questioning of Law Abiding Citizens, 75 Yale L.J. 1 I61 (1966); Remington \& Rosenblum; Robinson, supra note 3; Note, Kill or be Killed?: Use of Deadly Force in the Riot Situation, 56 Callf. L. Rtv. 829 (1968); Comment, Police Discretion and the Judgment that a Crime Has Been Committed-Rape in Philadelphia, 117 U. PA. L. Rev. 277 (1968).

11. See, e.g., Colo. Rev. Stat. Ann. \& 139-75-5 (1963); Oho Rev. Code Ans. \$ 737.11 (1954); note 8 supra.

12. "It is well known that some criminal statutes reflect the hope rather than the expeetation that the community will conform to the standard set forth in the statute." Remington \& Rosenblum 493. See also Kadish, supra note 9, at 909.

13. See, e.g., H. Goldstein 142-43; Kadish, supra note 9, at 908-09; Remington, The Role of Police in a Democratic Society. 56 J. CRIM. L.C. \& P.S. 361.362 (1965): The Right 10 Nondiscriminatory Enforcement $1120-21$. 
set policy for the police department so that some laws are enforced passively and others actively; ${ }^{14}$ the legislatures by default allow these legislative decisions to be made by the police.

What begins to emerge is a model for law enforcement and police behavior quite at odds with that implicit in the bare bones of legislative enactment. A realistic conceptual scheme, at a minimum; must take into account the following premises: while the legislature defines the outer limits of proscribed conduct, the police department defines the actual limits. ${ }^{15}$ Within the actual limits, the police department - or worse, individual policemen-decides which laws shall be enforced actively and which passively. ${ }^{16}$ For those laws that 'proscribe several distinguishable types of conduct, or restrict the same conduct in distinguishable situations, the police decide which types shall be actively or passively enforced. While some situations clearly require an arrest, others permit or compel the policeman to exercise discretion to determine whether to arrest or merely to give a warning or ignore the conduct completely. The individual policeman remains unfettered in the exercise of this judgment, and no discretionnarrowing administrative guidelines exist to check his whim, prejudice, or favoritism. ${ }^{17}$

The following figure illustrates a conceptualization of the enforcement of a broadly drawn penal statute which, as written, forbids the range of conduct encompassing behavior, let us say, D through $\mathrm{W}$.

14. See Walton, "Selective Distribution" of Police Patrol Force (pts. 1 \& 2), 49 J. CRıM. L.C. \& P.S. 165,379 (1958).

15. See, e.g., LaFave 108-11.

16. See, e.g., J. Goldstein 554-62.

17. "There are guidelines for wearing uniforms - but not for how to intervene in a domestic dispute; for the cleaning of a revolver-but not for when to fire it; for use of departmental property - but not for whether to break up a sidewalk gathering; for handling stray dogs-but not for handling field interrogations." NATIONAL ADVISORY COMMISSION ON CIVIL DISORDERS, Report of the National advisory Commission on Civil Disorders (KeRner Comm'N REP.) 164 (1968). See, e.g., Barrett, supra note 2, at 26-27; Foote, Law and Police Practice: Safeguards in the Law of Arrest,.52 Nw. U.L. REv. 16, 20 (1957); H. Goldstein,-Trial Judges and the Police, 14. CRIME \& DELIN. 14, 19 (1968); H. Goldstein, supra note 10, at 1126-28; H. Goldstein 143; Rotenburg. The Police Detection Practice of Encouragement, 49 VA. L. REv. 871,884 (1963); Note. Selective Detention and the Exclusionary Rule. 34 U. CH1. L. REv. 158 (1966); Police Discretion and the Judgment that a Crime Has Been Committed. supra note 10. 


\section{A B C D EFGH I JKL M N O P Q R S T U V W X Y Z}

$\frac{\mathrm{D}}{\text { (legislatively-defined outer limits) }}$

$\mathrm{H} \quad \mathrm{S}$

(administratively-defined actual limits)

$\underline{\mathrm{H}} \quad \mathrm{M}$

(áctive enforcement)

$\underline{\mathrm{N}} \mathrm{S}$

(passive enforcement)

$\underline{\mathrm{K} \quad \mathrm{P}}$

(routinely arrest)

$\underline{\mathrm{H}} \mathbf{\mathrm { J }}$

(discretionary arrest)

$\underline{D \quad G}$

(not enforced)
Q $\quad$ S

(discretionary arrest)

$$
\begin{aligned}
& \mathrm{X} Z \\
& \text { (arrest for legal conduct- } \\
& \text { perjury alleging illegal conduct) }
\end{aligned}
$$

The figure highlights those respects in which actual enforcement efforts are not constant for the entire range of conduct that the literal language of the statute purports to render criminal. ${ }^{18}$ lt is possible to distinguish five types of cases that may arise from enforcement:

I. The administrative exclusion of D-G from enforcement may

18. The figure suggests at least two problems which will not be discussed in this paper: first. the administratively-defined exemption of certain conduct (D-G) from enforcement may 
reflect the fact that of the legislatively prohibited conduct (D-W) the conduct represented by $D-G$ is characteristically engaged in by a favored class. ${ }^{19}$

II. The administrative decision to enforce $\mathrm{N}-\mathrm{S}$ passively results in the arrest of only a few of the many who engage in the forbidden conduct. ${ }^{20}$

III. Although arrests will routinely be made for K-P, the individual policeman has the power to exercise leniency if arrest seems unduly harsh under the circumstances, and his judgment as to those circumstances is likely to result in leniency in favor of those whom his own prejudices favor. ${ }^{21}$

IV. Passive enforcement of $\mathrm{N}-\mathrm{S}$ allows the police to select individuals for prosecution. Likewise, the availability of arrest for $\mathrm{T}$ $W$ gives them discretionary authority-while nearly everyone engages in conduct within this range, the police can arrest a disfavored individual for ostensibly engaging in the proscribed conduct. ${ }^{22}$

$\mathrm{V}$. In situations $\mathrm{H}-\mathrm{J}$ and $\mathrm{Q}-\mathrm{S}$ the individual policeman's discretion is not normally narrowed by departmental guidelines setting forth considerations for him to weigh in deciding to arrest, to give a warning, or to ignore the violation. ${ }^{23}$

eventually make the law desuetudenal as to that conduct; see Berry, Spirits of the Past-Coping With Old Laws, 19 U. FLA. L. REv. 24 (1966); and second, the police, as a practical matter, have the power to arrest for conduct $(X-Z)$ which is outside the scope of the legislative proscription, and to testify that the conduct was within the legislative proscription. While police perjury may be all too common, courts seldom take the word of the accused over that of the police. See generally P. CHEVIGNY, supra note 10.

19. For example, poker games at gentlemen's clubs are thereby exempted from the reach of a gambling statute.

20. For cxample, laws forbidding possession of marijuana are enforced only against a few randomly-selected scapegoats.

21. For example, the son of the bank president is not arrested when stopped for drunken driving.

22. For example, the owner of the shop where a radical newspaper is printed may be charged with violation of an obscure building code provision.

23. For example, he can decide to arrest someone playing a harmonica in the park simply because he finds him arrogant or does not like his long hair. For the leading example of advocacy of this means of social control by a former United States Attorney General, see 1. Arnold, The Symbols of Government 160 (1935). Paulsen, Civil Liberties and the Proposals to Curb Organized Crime, 38 Notre Dame Law. 699, 703 (1963), for similar views of Attorney General Robert Kennedy. See also Miller, Administrative Agency Intelligence-Gathering: An Appraisal of the Investigative Powers of the Internal Revenue Service, 6 B.C. IND. \& CoM. L. REv. 657 (1965). 
With at least 350,000 individual policemen ${ }^{24}$ throughout this country, the fifth category undoubtedly accounts for the greatest abuse. Because instances of discriminatory enforcement are of such low visibility and are so difficult to prove, however, few are to be found in the case reports. Consequently, it is in the area of Type $V$ discrimination that the insulation of individual policemen from judicial scrutiny should be attacked. But adequate conceptual weapons have not yet been forged. The ambition of this article, therefore, is to assist in shaping those weapons by clarifying and criticizing the related concepts underlying and arising from the other four categories of discriminatory enforcement.

\section{Discriminatory Enforcement CaSes in the Supreme Court}

The Supreme Court has rarely been called upon to deal with issues of discriminatory enforcement. The first and most important of the cases it has decided was Yick Wo v. Hopkins. ${ }^{25}$ That case arose under a San Francisco ordinance which required all laundrymen desiring to continue business in wooden buildings to obtain the consent of a board of supervisors, making operation without such consent a misdemeanor punishable by imprisonment. Yick Wo, a laundry operator, was imprisoned for operating without a license, and sought a writ of habeas corpus. He argued that the ordinance although purporting to be a non-discriminatory regulation to prevent fire hazards, by its own terms contained no safeguard against discriminatory enforcement, and, in fact was enforced in a discriminatory fashion against Chinese. He alleged that the supervisors had withheld consent from all but one of the approximately 240 Chinese operators while allowing all of the 80-odd Caucasian operators to continue operating in wooden buildings. Finding the ordinance unconstitutional both as applied and as written insofar as it vested unbridled discretion in the board of supervisors, the Court ordered Yick Wo released.

The Court found that the ordinance did not confer a limited discretion but rather "a naked and arbitrary power to give or withhold consent ... [and] not confided to their discretion in the legal sense of that term .... It is purely arbitrary, and acknowledges neither guidance nor restraint." ${ }^{26}$ Approving Yick Wo's first contention, that the ordinance was void on its face, the

24. This approximation of the number of policemen, as of 1960. appears in Sax, Why /I Hurts to be Black and Blue. 4 Issues IN CRIMINOLOGY 1. 7 (1968).

25. 118 U.S. 356 (1886).

26. Id. at 366-67. 
Court stated that "the very idea that one man may be compelled to hold his life, or the means of living, or any material right essential to the enjoyment of life, at the mere will of another, seems to be intolerable in any country where freedom prevails, as being the essence of slavery itself." 27 Moreover, official action or non-action could be premised upon bias, prejudice and other improper influences that would be difficult to prove. ${ }^{28}$

However, the Court found it unnecessary to base its decision on the language of the ordinance which afforded opportunities for "unequal and unjust discrimination in their administration." 29 Yick Wo had also contended the ordinance was void as applied because a disfavored class was punished while a favored class was permitted to continue in business without any distinction of circumstances-unjust and illegal discrimination-made possible by the ordinance. Finding discriminatory administration of the ordinance, the Court uttered its much-quoted observation:

Though the law itself be fair on its face and impartial in appearance, yet, if it is applied and administered ... with an evil eye and an unequal hand, so as practically to make unjust and illegal discriminations between persons in similar circumstances, material to their rights, the denial of justice is still within the prohibition of the Constitution. ${ }^{30}$

Federal and state cases following Yick $W o$, however, have greatly narrowed the application of its apparently broad-sweeping principles. Subsequent cases introduced distinctions and problems of proof not suggested by Yick $W o$, thus indicating the power of an unsympathetic court to eviscerate the Yick Wo remedy. In Crowley v. Christensen, ${ }^{31}$ the Court, finding that the ordinance vested complete discretion in the police chief, as in Yick Wo, noted that the police chief had good cause to revoke Christensen's saloon license. Yick Wo was distinguished on the further ground that an inherent difference between a "harmless" laundry and the business of operating a saloon somehow rendered the police chief's exercise of unbridled discretion less obnoxious. ${ }^{32}$ The 1905 case of $A$ h Sin v. Whitman ${ }^{33}$ introduced problems of proof and pleading that have continued to plague petitioners. Following his
27. Id. at 370 .
28. Id. at 373 .
29. Id.
30. Id. at 373-74.
31. 137 U.S. 86 (1890).
32. Id. at $90-91$.
33. 198 U.S. 500 (1905). 
conviction for violating an ordinance forbidding presence in a locked room containing exposed gambling tables, Ah Sin sought a writ of habeas corpus on the grounds that the ordinance was enforced solely against Chinese. The Supreme Court, however, affirmed the denial of the writ finding that petitioner's allegation was insufficient for failure to allege "that the conditions and practices to which the ordinance was directed did not exist exclusively among the Chinese" and that there were non-Chinese offenders against whom the ordinance was not enforced. ${ }^{34}$

In Oyler v. Boles ${ }^{35}$ the Court rejected the petitioners' claim that their sentences to life imprisonment under West Virginia's habitual criminal statute constituted discrimination violative of the fourteenth amendment. The statute by its own terms was to be automatically triggered upon conviction for a third felony; in fact, Oyler alleged, he alone among six such offenders, was subjected to its provisions by the Taylor County Court; and moreover, 904 persons throughout the state had escaped its sanctions. The Court stressed that the record did not exclude the possibility that the failure to proceed against other three-time offenders was due to lack of knowledge of the prior offenses on the part of the prosecutors concluding that "the allegations set out no more than a failure to prosecute others because of a lack of knowledge of their prior offenses." 36 Thus the complaint did not allege a denial of equal protection.

It is arguable whether Oyler stands precisely for the proposition that essential to any claim of discriminatory enforcement is the allegation that the enforcement agency is aware of the other violations that it allegedly has failed to proceed against. If this is its principle, it adds little to $A h$ Sin's requirement that the existence of other violat ors be affirmatively pleaded. However, the Court indicated "the conscious exercise of some selectivity in enforcement is not in itself a federal constitutional violation. . . . [unless the selection is] based upon an unjustifiable standard such as race, religion, or other arbitrary classification." ${ }^{37}$ This suggests that selectivity based upon a

34. Id. at 507. A suspicion that the Court had prejudged the ultimate question arises from its observation that Yick Wo

concerned the use of property for lawful and legitimate purposes. [.Ah Sin] is concerned with gambling, to suppress it is recognized as a proper exercise of governmental authority, [an exercise] which would have no incentive in race or class discrimination. Id. 35. 368 U.S. 448 (1962).

36. Id. at 456 .

37. Id. 
"justifiable standard" is always permissible. But Oyler is probably not applicable to cases involving the exercise of such selectivity by police, inasmuch as the discretion involved was that of the prosecutor who, by tradition, has the very widest latitude in this area ${ }^{38}$

Two tax assessment cases, involving property rights rather than personal liberty, have been widely viewed as further limiting Yick Wo. In Sunday Lake Iron Co. v. Wakefield ${ }^{39}$ the Court rejected Sunday Lake's claim that the assessment of its property at full value for tax purposes while other companies were assessed at one-third their worth violated the equal protection clause of the fourteenth amendment. Noting that the State Board of Tax Assessors had neither the time to re-assess the properties of the other companies nor sufficient evidence to justify a summary adjustment, the Court introduced an element of "good-faith" to uphold the action of the Board. Specifically, the Court found that petitioner had failed to prove a lack of good faith and held that "mere errors of judgment by officials will not support a claim of discrimination. There must be something more-something which in effect amounts to an intentional violation of the essential principle of practical uniformity." 40 In the second tax assessment case, Mackay Telegraph \& Cable Co. v. Little Rock, ${ }^{41}$ the alleged discrimination lay not in a differential rate, but in a failure to enforce a tax on telegraph poles against two competitor companies. The Court reiterated the requirement that a petitioner allege "arbitrary and intentionally unfair discrimination" and noted that the enforcement of a telegraph pole tax against Mackay may have been a test case to determine whether license fees might validly be imposed in the circumstances "with [the] intent, in case of an affirmative answer, to enforce the general ordinance against the other companies." 42

38. It should be observed, too, that the Court declined to decide whether the statute did in fact impose the mandatory duty that the petitioners had alleged. $I d$.

39. 247 U.S. 350 (1918).

40. Id. at 353 .

41. 250 U.S. 94 (1919).

42. Id. at 100 . It should be noted that the Court was not entirely satisfied that the circumstances of the two other companies wcre similar to the petitioners.

See also Moog Indus.. Inc. v. FTC, 355 U.S. 411 (1958), where the Court, in a per curiam opinion, upheld the power of the FTC to issue a cease and desist order against one firm while allowing that firm's competitors to persist in the same unfair trade practice. Two commentators who would rely on Moog to give police the power to single out certain offenders for arrest, Remington \& Rosenblum 492; Remington, supra note 3, at 363, overlook the fact that the Court deferred to the expertise of the Commission in its exercise of a discretion expressly conferred by Congress. Congress had specifically empowered the Commission "to develop that enforcement policy best calculated to achieve the ends contemplated by Congress and to allocate its available 
Further pleading difficulties were imposed upon the plaintiff in the civil rights case of Snowden v. Hughes. ${ }^{43}$ In the 1940 Republican primary for nomination for the Illinois General Assembly, Snowden, a Negro, ${ }^{-4}$ placed second. Illinois election laws provided that the two highest vote getters in the Republican primary and the one winner in the Democratic primary were to be placed on the ballot in the general election. Three representatives were to be elected from the district, and thus Snowden's second-place finish in the Republican primary was tantamount to election; however, the State Primary Canvassing Board, in violation of state law, failed to certify Snowden, certifying instead only the one highest vote-getter from both the Republican and Democratic primaries. Snowden, deprived of election to office, brought suit in federal district court against the members of the State Board for $\$ 50,000$ damages..$^{45}$ The Supreme Court in dismissing held Snowden's pleadings inadequate for failure to allege "purposeful discrimination." Where Sunday Lake held only that "something more" must be shown than "mere errors of judgment," namely, the "intentional violation of the essential principle of practical uniformity," Snowden seemingly held that selective enforcement is always permissible unless the victim can prove that he has been intentionally singled out for personal victimization. The puzzling aspect of Snowden is that the pleadings had alleged "willful" and "malicious" discrimination-yet the Court dismissed these as mere "opprobrious epithets." 46

In a Sunday closing case, Two Guys from Harrison-Allentown, Inc. $v . M c$ Ginley ${ }^{47}$ the petitioners alleged that the prosecutor had invidiously singled them out as his exclusive target. In declining to enjoin their pending prosecutions, the Court dispelled any possible

funds and personnel in such a way as to execute its policy efficiently and economically." 355 U.S. at 413. The narrowness of the decision is apparent in the Court's statement that deference to the Commission in this instance "is but recognition of the fact that in the shaping of its remedies within the framework of regulatory legislation, an agency is called upon to exercise its specialized experienced judgment." Id.

43. 321 U.S. I (1944).

44. The Court does not advert to Snowden's race. But see 32 GEo. L.J. 435 (1944).

45. The action was based on statutes now codified at 42 U.S.C. $\$ \S 1981.1983 \& 1985(3)$ (1964).

46. 321 U.S. at 10. Reliance on Snowden to defeat claims of discriminatory enforcement is disquieting because Snowden, in all material aspects, has been deprived of its vitality by subsequent cases. See Monroe v. Pape, 365 U.S. 167 (1961): Whirl v. Kern, 407 F.2d 781 (5th (ir. 1969): Joseph v. Rowlen, 302 F.2d 367 (7th Cir. 1968): Beauregard v. Wingard, 362 F.2d 901 (9th Cir. 1966); Cohen v. Norris. 300 F.2d 24. 27-30 (9th Cir. 1962).

47. 366 U.S. 582 (1961). 
doubt that the Yick Wo rationale is fully available to the defendant in a discriminatory penal-law enforcement case by stressing that an adequate remedy exists at law since the discrimination, if proved, would be a sufficient defense to their pending criminal prosecution. ${ }^{48}$

\section{Discriminatory Enforcement Cases in State and lower Federal Courts}

Type I: Cases in which enforcement officials immunize from arrest and prosecution conduct $(D-G)$ that is within the bounds of the legislative proscription $(D-W)$.

In this category fall those cases in which law enforcement officials conceptualize the conduct of a subclass of violators as "different" from that of others and prosecute one class while exempting the other. One would expect the courts, in cases of this genre, to face squarely the question whether police and prosecutors have the power to narrow a legislative proscription in any situation and, if such selectivity is not invalid per se, what standards are applicable in evaluating such classifications. In practice, however, the courts have generally ignored these questions and have considered such cases under an assumption that a classification is valid if it is one that the legislature could validly have made, even though the legislature itself did not see fit to make it. ${ }^{49}$

A number of cases seem to be based upon this implicit, unarticulated assumption. For example, in Gardner v. Benoit ${ }^{50}$ the First Circuit rejected an argument that a decision of a state crime commission to focus its investigations on corruption among state officials violated the fourteenth amendment. While the discrimination might deny equal protection under other circumstances, the court found the classification served a valid state interest, concluding that

48. Id. at 588-89. The Court also noted that the need for an injunction had vanished during the pendency of the litigation when the prosecutor's (who had threatened the discrimination) term of office had expired.

49. See C. Black, Structure and Relationship in Constitutional. Law 88-93 (1969). Two cases suggest that when the exercise of arbitrary discretion is facilitated by the legislation under whose authority the discretionary act is performed, the legislation may be unconstitutional, not only "as applied," but "on its face" as well, insofar as it facially confers readily-abusable discretion. United States v. Louisiana, 225 F. Supp. 353, 391 (E.D. La. 1963) (three-judge court); Davis v. Schnell, 81 F. Supp. 872, 880 (S.D. Ala. 1949) (three-judge court). Thus, the appropriate remedy for discriminatory enforcement may, in some circumstances, include a declaration that the substantive criminal law invoked is itself unconstitutional for the discretion it contemplates.

50. 35 I F.2d 846 (Ist Cir. 1965). 
"those appointed to high public office hold a special public trust; they cannot properly complain if they are the objects of special scrutiny." A similar rationale might justify decisions rejecting equal protection claims in cases where prosecutors offer amnesty to all givers of bribes who testify against receivers of bribes where the applicable statute proscribes both giving and receiving, ${ }^{52}$ or cases where landlords, but not tenants, are prosecuted under a housing-repair law facially applicable to both; ${ }^{53}$ and to prosecutions for blowing up a bridge in a friendly foreign country while saboteurs against hostile nations are not arrested. ${ }^{54}$

However, connection between the classification and a valid state interest becomes more attenuated as the propriety of classifications by enforcement officials, who are not directly answerable to the electorate nor charged with the making of policy, becomes more questionable. For example, while it may be possible to discover a reason to permit escrow clerks of banks to do what is forbidden to real estate brokers, ${ }^{55}$ or to permit gambling establishments specializing in election bets to flourish while outlawing horse-race betting, ${ }^{56}$ one would anticipate that a court would not permit the police to make such distinctions under a statute proscribing such conduct generally. However, in each of these cases the court rejected petitioner's claims, saying that the failure to prosecute some guilty persons does not deny equal protection to guilty persons who are prosecuted. ${ }^{57}$

The most familiar cases involving arrogation of legislative power concern selective police enforcement of Sunday Blue Laws. ${ }^{58}$ The

51. Id. at 849 .

52. Saunders v. Lowry, 58 F.2d 158 (5th Cir. 1932). The court based its decision, in part, on the right-privilege distinction which it felt $A h$ Sin had imported into the Yick Wo doctrine. Thus the vital difference is the one betwcen "the right to use property for a lawful purpose and the claim of a privilege to visit a gambling house which the state, in the exercise of its police power, could suppress at pleasure." Id. at 159.

53. 300 West 154th Street Realty Co. v. Department of Bldgs., 30 App. Div. 2d 351.292 N.Y.S.2d 25 (1968).

54. United States v. Elliott, 266 F. Supp. 318 (S.D.N.Y. 1967).

55. People v. Sipper. 61 Cal. App. 2d 844, 142 P.2d 960 (Super. Ct. 1943).

56. People v. Oreck, 74 Cal. App. 2d 215. 168 P.2d 186 (Ct. App. 1946).

57. Id. at 221, 168 P.2d at 191; People v. Sipper, 61 Cal. App. 2d 844, 848, 142 P.2d 960. 963 (Super. Ct. 1943).

58. The problem of attributing rational purpose to a pattern of enforcement that exempts certain classes of establishments is especially confused in these cases because of the epic generosity of the Supreme Court in McGowan v. Marylund. 366 U.S. 420 (1961), in finding rationality in the exemption intricacies that were written into the law itself. 
lower courts have, for the most part, ignored the police arrogation issue noting simply that no evidence established that other businessman of the same sort as the person prosecuted had been exempted from prosecution ${ }^{59}$ and treating evidence that businesses which, though of another sort, were equally covered by the law yet not prosecuted, as irrelevant..$^{60}$ Two cases, ${ }^{61}$ however, provoked thoughtful dissent, the judge in one specifically noting that since the legislature did not see fit to distinguish grocery stores from other mercantile establishments, the administrative officers of the state are powerless to inflict such discrimination by selective enforcement. ${ }^{62}$

However, three cases faced the issue squarely and reached a logically justifiable result. A New York court has disapproved enforcement of a building code and zoning ordinance solely against non-parochial schools when it was facially applicable to parochial schools as well. ${ }^{63}$ Similarly, the Kentucky Court of Appeals has enjoined the selective enforcement of the state's Sunday closing law ${ }^{64}$ and a law forbidding the display of merchandise on the sidewalk. ${ }^{65}$

The answer to the problems in Type I cases is obvious, but not simple-the courts must establish meaningful standards to be used in evaluating the validity of the criteria relied upon by police and prosecutors to distinguish between subclasses of violators. As a practical matter, the courts must recognize the power of the police to narrow the legislative proscription by selective enforcement in some cases - unless the police have the capacity to arrest and prosecute every violator of a statute. The police must have discretion to select, on reasonable grounds, those violators who are to be arrested. It is suggested that the courts, rather than making the cursory inquiry

59. Highland Sales Corp. v. Vance, 244 Ind. 20, 186 N.E.2d 682 (1962); People v. Pam, 38 Misc. 2d 296, 238 N.Y.S.2d 363 (N.Y. City Crim. Ct. 1963); State v. Gamble Skogmo, Inc., 144 N.W.2d 749 (N.D. 1966).

60. In Bargain City USA, Inc. v. Dilworth, $407 \mathrm{~Pa} .129,179$ A.2d 439 (1962), the Pennsylvania Supreme Court reversed the lower court, which had enjoined the Philadelphia Police Commissioner from executing his announced policy of enforcing the Sunday closing law against large retail establishments. The court, effectively re-writing Yick Wo, asserted "the constitutionality of the statute cannot be governed by its enforcement unless the discrimination in enforcment flows directly from a discrimination intended by the statute . . . " Id. at 134, 179 A.2d at 443.

61. Taylor v. Pine Bluff, 226 Ark. 309, 313, 289 S.W.2d 679, 681 (1956); Commonwealth v. Bauder, 188 Pa. Super. 424, 426, 145 A.2d 915, 925 (1958).

62. Taylor v. Pine Bluff, 226 Ark. 309, 3I6, 289 S.W.2d 679, 683 (I956).

63. Betty-June School, Inc. v. Young, 25 Misc. 2d 909, 201 N.Y.S.2d 692 (Sup. Ct. 1960).

64. Ashland v. Heck's, Inc., 407 S.W.2d 421 (Ky. 1966).

65. Covington v. Gausepohl, 250 Ky. 323, 62 S.W.2d 1040 (1933). 
whether the legislature could validly have made the distinction, place the burden on the prosecution to demonstrate that the reasons for viewing the various subclasses of violators as different are valid, the classes of violators they have selected to prosecute are more "worthy" of prosecution than those not arrested, and the classifications are necessitated by administrative and prosecutorial factors. Further, the prosecutor should be charged with establishing that the particular defendant fits within the classification, is not being discriminated against for other reasons, and that attempts are being made to broaden the class of violators subject to prosecution. The burden on the prosecution is, and should be, heavy. While it may be difficult for the prosecution to rebut the allegation of unjustified discriminatory enforcement, it is almost impossible for a defendant to affirmatively prove the presence of invidious discrimination.

Type II: Cases in which enforcement officials' decision to enforce certain conduct $(N-S)$ only passively results in the arrest of only a fraction of violators.

In cases in this category the law enforcement officials, rather than claiming that the conduct of unprosecuted violators is conceptually different from that of those who are prosecuted in Type I cases, assert that total enforcement is impossible or impractical and that selective enforcement is unobjectionable so long as the basis for selection is neutral and not invidious. The most persuasive cases of this nature are those involving situations where enforcement agencies lack the resources to detect and prosecute all violators ${ }^{65}$ or cases where a prosecution simply happens to be the first such brought, ${ }^{67}$ perhaps even as a test case ${ }^{68}$ and nothing suggests that other prosecutions will not follow-especially when the first person prosecuted is a notorious and egregious offender ${ }^{69}$ Courts have given blanket approval in these types of cases.

66. Thompson v. Spear, 91 F.2d 430 (5th Cir. 1937); Powers v. Floersheim, 256 Cal. App. 2d 223, 63 Cal. Rptr. 913 (Ct. App. 1967).

67. Ehrlich v. McConnell. 214 Cal. App. 2d 280. 29 Cal. Rptr. 283 (Ct. App. 1963); San Francisco v. Burton, 201 Cal. App. 2d 749. 20 Cal. Rptr. 378 (Ct. App. 1962); People v. Gordon. 105 Cal. App. 2d 711. 234 P.2d 287 (Ct. App. 1951); see Boynton v. Fox West Coast Theatres Corp.,.60 F.2d 851 (10th Cir. 1932).

68. People v. Gödōn, 105 Cal. App. 2d 711. 722.234 P.2d 287. 294 (Ct. App. 1951).

69. Powers v. Floersheim. 256 Cal. App. 2d 223. 63 Cal. Rptr. 913 (Ct. App. 1967); Highland Sales Corp. v. Vance. 244 Ind. 20. 186 N.E.2d 682 (1962); cf. Takata v. Los Angeles, 184 Cal. App. 2d 154. 7 Cal. Rptr. 516 (Ct. App. 1960): People v. Pope, 168 Cal. App. 2d 666, 336 P.2d 236 (Ct. App. 1959); State v. Sage Stores Co., 157 Kan. 404 . 141 P.2d 655 (1943). 
However, a number of courts have simply invoked the overlybroad shibboleth that "laxity" in enforcement is not sufficient to amount to a denial of equal protection. "20 "Laxity" is a description, not a reason; such shallow reasoning neither provides a justification for selective enforcement, nor rebuts inferences of invidiousness that might be drawn from the selection of a particular victim. In effect, the cases that simply invoke the "laxity" shibboleth are no better reasoned than the cases that flatly announce their conclusion with no pretense of affirmative justification. ${ }^{71}$

The problems inherent in a facile judicial rejection of arguments against selective enforcement are strikingly illustrated by the enforcement of a Sunday closing law in South Euclid $v$. Bondy. ${ }^{72}$ In Bondy, although there were 15 competitive stores within view of Bondy's store, he was the first arrested under the new law. The court, not unexpectedly, rejected Bondy's petition on the grounds that someone must always be the first to be prosecuted. However, one year later Bondy again petitioned the court for relief, ${ }^{73}$ pointing out that while none of his competitors had yet been prosecuted, he had been arrested three times. Bondy was nevertheless again denied relief because he was unable to show intentional discrimination. While noting that "Bondy has not merely been prosecuted . . . he is being persecuted [and] [t] his is a shameful thing to be happening in our great democracy," 74 the court affirmed Bondy's conviction. Disadvantage to the persons selectively prosecuted is not confined to economic competition cases. The person who is arrested for a victimless crime such as possession of marijuana is a scapegoat. The

70. Nelson v. State. 387 P.2d 933 (Alaska 1964) (laxity in applying prescribed standards in Fish and Game Board hearing for the wrongful taking of a cub grizzly bear); Ratkovich v. San Bruno, 245 Cal. App. 2d 870, 54 Cal. Rptr. 333 (Ct. App. 1966) (laxity in billing large trucks for use of city streets): Yanke v. State Dep't of Pub. Health, 162 Cal. App. 2d 600, 328 P.2d 556 (Cl. App. 1958) (laxity in licensing convalescent homes); People v. Millstein, 54 Misc. 2d 65I, 283 N.Y.S.2d 353 (Long Beach City Ct. 1967) (laxity in enforcing zoning ordinances); State v. Gamble Skogmo, Inc., 144 N.W.2d 749 (N.D. 1966) (laxity in enforcing Sunday closing law).

71. See People v. Linden, 204 Cal. App. 2d 745, 22 Cal. Rptr. 633 (Ct. App. 1962); Atherton v. Templeton, 198 Cal. App. 146, 17 Cal. Rptr. 680 (Ct. App. 1961); Midwest Inv. Co. v. Chariton. 248 lowa 407. 80 N.W.2d 906 (1957); Garrison v. Menendez, 158 So. 2d 856 (La. Ct. App. 1964); People v. Freidman, 302 N.Y. 75, 96 N.E.2d 184 (1950); People v. Derison, 57 Misc. 2d 1003, 294 N.Y.S.2d 339 (Long Beach City Ct. 1968).

72. 26 Ohio Op. 2d 69.92 Ohio L. Abs. 108, 192 N.E.2d 139 (South Euclid Mun. Ct. 1963).

73. South Euclid v. Bondy. 28 Ohio Op. 2d 316, 95 Ohio L. Abs. 296, 200 N.E.2d 508 (South Euclid Mun. Ct. 1964).

74. Id. at 320.95 Ohio L. Abs. at 304. 200 N.E.2d at 512-13. 
failure to enforce the law against the vast majority of violators relegates the occasional victim to a solitary doom. ${ }^{75}$

In only one case, United States $v$. Dawson, ${ }^{76}$ has a court been sympathetic to the assertion that a mere showing of other unprosecuted violators can be sufficient to constitute a denial of equal protection $^{77}$ and that not even an allegation of intentional discrimination is needed to support an equal protection claim. ${ }^{78}$ In Dawson, the Second Circuit implied that a political leader prosecuted for violating tax laws could establish a denial of equal protection under Yick Wo merely by showing that other political leaders who had similarly diverted political funds had not been prosecuted.

75. An additional deficiency in the judicial treatment of selective enforcement cases is the occasional tendency toward duplicity. Courts are not always able to resist the temptation of slapping on the "selective enforcement" label, ignoring the presence of allegations of invidious discrimination. In Moss v. Hornig, 214 F. Supp. 324 (D. Conn. 1962), the court dismissed a suil seeking to enjoin a pending prosecution for violation of a Sunday closing law. The court repeated the familiar incantation that the failure to prosecute others does not make out an equal protection claim, and swept aside the plaintiff's assertion that the Chamber of Commerce had used the enforcement against him as "a weapon of economic pressure" with the off-handed remark that he had failed to claim a connection between the Chamber of Commerce and the prosecution. Id. at 332. In Buxborn v. Riverside, 29 F. Supp. 3 (S.D. Cal. 1939), the courl rejected a complaint for failure to allege arbitrary discrimination even though the plaintiff had alleged that a competitor had been openly and continuously violating the same law, that the defendants knew of the violation, and that they knowingly and wilfully had refused to prosecute him. See also Hickinbotham v. State, 227 Ark. 1032, 303 \$.W.2d 565 (1957).

More straightforward, though equally obstructionistic, are those courts which deny that discriminatory enforcement can ever amount to a deprivation of equal protection. See State $v$. Haase, 97 Ohio App. 377, 116 N.E.2d 224 (1953) ("The fact that one person is prosecuted and another is not, is a subject with which the court cannot deal." Id. at 389, 116 N.E.2d at 230); State v. Corologos, 101 Vt. 300, 143 A. 284 (1928) ("[l]t was a discrimination in the administration of the law and not in the law itself, and manifestly had no bearing on the question of respondents' guilt or innocence. One offender cannot excuse his conduct by showing that someone else equally guilty has not been prosecuted." Id. at 307, 143 A. at 287-88). See also Eastwood Park Amusement Co. v. Mayor, 325 Mich. 60, 38 N.W.2d 77 (1949).

For the suggestion that the defendant be given the status of "private attorney-general" to raise the public policy issues raised by selective enforcement, see Remington \& Rosenblum 498.

76. 400 F.2d 194 (2d Cir. 1968), cert. denied, 393 U.S. 1023 (1969).

77. In New Orleans v. Levy, 233 La. 844,98 So. 2d 210 (1957), the court reversed a lower court decree which had ordered the defendant to remove an awning that violated a zoning ordinance. The court stated that Levy, the first person whom the city had ever hauled into court for an injunction without previousty seeking administrative compliance. made out a prima facie case of discrimination when he proved the existence of many unrestrained violators. "Thereupon, the burden of going forward with the evidence, to explain its apparently discriminatory conduct shifted to the city." Id. at 854,98 So. $2 \mathrm{~d}$ at 213 . However, on rehearing, id. at 862,98 So. $2 d$ at 217 , the court retreated, and reinterpreted its earlier decision as a merc denial of equitable relief to a city which had come into court with unclean hands. The court expressly renounced any suggestion that a mere showing of other unprosecuted violators, absent a showing of invidious discrimination, is sufficient to establish denial of equal protection.

78. 400 F.2d at 204. 
Here, as in Type I cases, a means of avoiding inequities that might arise from selective enforcement premised upon impossibility or impracticality is placing the burden upon the prosecution of rebutting the defendant's allegation of invidious discrimination. With only one case supporting an equal protection claim that did not allege intentional discrimination, it is unrealistic-and probably unnecessary - to expect the courts to drop the requirement of an intentional discrimination allegation. Without enlisting the entire citizenry into the police corps there probably can never be enough police to arrest and prosecute all violators of a given ordinance. However, when a defendant alleges invidious discrimination and presents a minimum of proof supporting his allegation, the burden of establishing the neutrality of the selection should shift immediately to the state. Further, evidence offered by the defendant showing the numbers and types of individuals who have been prosecuted for similar violations and those who have escaped prosecution should not be dismissed as irrelevant.

Type III: Cases in which an individual policeman exercising "leniency" fails to arrest the violator, although he routinely arrests all other violators in similar cases $(K-P)$.

Type Ill cases differ from Type II cases, because in Type III situations it is the failure to arrest that is extraordinary and the discrimination results from the favoritism toward the person who is not arrested. Admittedly, there is often a valid justification for a policeman's failure to arrest a violator. The offense may be a minor one and a warning may serve as the necessary deterrent, or the circumstances of the offense might indicate that the violator is justifiably unaware of his violation, or so innocent of mind that the policeman concludes that arrest is unwarranted and unnecessary.

However, there is at least one case ${ }^{79}$ indicating the possibility of

79. There are several other cases involving "leniency" by prosecutors and judges. Involving prosecutorial discretion, these cases have little analogical significance for police "leniency." $C f$. United States v. Rundle, 270 F. Supp. 55 (E.D. Pa. 1967) (choice to not prosecute an admitted perjurer so that he would be available to testify against defendant); People v. Maldanado, 240 Cal. App. 2d 812, 50 Cal. Rptr. 45 (Ct. App. 1966) (refusal of a judge to dísmiss complaint against a Puerto Rican and a black defendant after he had dismissed an identical complaint arising from the same incident for two white defendants); People v. Hess, $104 \mathrm{Cal}$. App. 2d 642 , 234 P.2d 65 (Ct. App. 1951) (failure to prosecute other state officials engaged in the same misconduct): State v. Jourdain, $225 \mathrm{La}$. 1030, 74 So. 2d 203 (1954) (failure to give narcotics 
abuse and the fate of a citizen who attempted to bring the discrimination to light. In Application of Finn, ${ }^{80}$ Finn was stopped by a policeman while driving at night, and charged with having only one headlight and no light illuminating his license plate. Noticing that the police car also had no light illuminating its license plate, Finn sought to make a citizen's arrest of the officer who had arrested him. At his trial, Finn sought to subpoena the police chief and four policemen to prove discriminatory enforcement. But the California Supreme Court, relying on a Type II rationale, recited the shibboleth that failure to arrest others equally guilty is no defense and found no error in the trial court's refusal to issue the subpoena. ${ }^{81}$ Finn was ultimately one of the few unlucky citizens who have gone to jail for the charges indicated.

Type III cases are, as indicated by the sparsity of cases, of very low visibility. However, when a court is presented with allegations of this type of favoritism, it should face the issue squarely and avoid the stock answer that failure to arrest others equally guilty is no defense. Instead, the court should determine if the state has a valid justification for the favoritism alleged, and absent a showing of a valid classification the defendant's equal protection claim should be a complete defense. While the dismissal of charges against the defendant may seem harsh, it is submitted that the deterrent effect of dismissal upon future police misconduct justifies the result.

Type IV. Cases in which the person arrested for engaging in'conduct normally only passively enforced, alleges that he has been invidiously singled out $(N-W)$.

Cases in this category, involving the allegation of invidious discrimination, have evoked the judicial requirement, disastrous in all but a few cases, that the claimant allege and prove "intentional or purposeful discrimination." It is within this category that one finds some of the most outrageous examples of judicial abdication.

The most disturbing cases involve courts who give lip service to the "intent" requirement, but whose decisions belie their apparent conviction that discriminatory enforcement can never amount to a

defendant the opportunity given others to become an informer); Sherman v. State, 234 Miss. 775,108 So. $2 \mathrm{~d} 205$ (1959) (failure to give embezzlement defendant the opportunity given others to make restitution).

80. 54 Cal. 2d 807, 356 P.2d 685. 8 Cal. Rptr. 741 (1960).

81. Id. at 812,356 P.2d at 688.8 Cal. Rptr. at 744 . 
denial of equal protection-some cases withhold even lip service and dismiss equal protection claims summarily. ${ }^{82}$ These latter cases at least have the virtue of candor in that they do not pretend that there is a quantum of proof of invidious intent that would persuade them to accept equal protection claims. ${ }^{83}$ The Florida Supreme Court has stated that even if the record had proved that the defendant had been the victim of "inordinate prejudice" that fact would not be material; 84

82. The rationales offered to distinguish the Yick Wo doctrine are thoroughly discredited in The Right to Nondiscriminatory Enforcement. The arguments typically resorted to may fairly be paraphrased as follows: one, Yick Wo only requires that persons engaged in a lawful occupation be free from discriminatory enforcement of laws regulating that oceupation. Persons who violate laws have no right to do so, and have no claim to non-discriminatory enforcement. See People v. Flanders, 140 Cal. App. 2d 765, 296 P.2d 13 (Ct. App. 1956); People v. Darcy, 59 Cal. App. 2d 342, 139 P.2d 118 (Ct. App. 1943); People v. Winters, 171 Cal. App. 2d 876, 342 P.2d 538 (App. Dep't 1959). But see The, Right to Nondiscriminatory Enforcement 1107-12; two, as a matter of public policy, persons who admittedly have violated the law should not be exonerated simply because other violators have not been prosecuted-even if their selection was discriminatory. See People v. Flanders, 140 Cal. App. 2d 765, 296 P.2d 13 (Ct. App. 1956); People v. Winters, 171 Cal. App. 2d 876, 342 P.2d 538 (App. Dep't 1959). But see The Right to Nondiscriminatory Enforcement 1107-12; three, the ordinances in Yick Wo delegated discretion to the administrative officials. Police, on the contrary, have no delegated discretion. See Society of Good Neighbors v. Van Antwerp, 324 Mich. 22, 36 N.W.2d 308 (1949). But see The Right to Nondiscriminatory Enforcement 1107-08 n.17, $1111 \mathrm{n.42}$; and four, the ordinances in Yick Wo were intentionally drafted so as to facilitate discrimination. Therefore, Yick Wo does not apply to discriminatory enforcement that was not contemplated by the law. See Bargain City USA, inc. v. Dilworth, 407 Pa. 129, 179 A.2d 439 (1962); Commonwealth v. Bauder, 188 Pa. Super. 424, 145 A.2d 915 (1958) (both Type I cases). But see The Right to Nondiscriminatory Enforcement 1108 n. 17,1111 n.42.

In addition, two courts have refused injunctive relief as a remedy, relying on the now-quaint doctrine that equity protects only property rights. See Jackie Cab Co. v. Chicago Park Dist., 366 11l. 474, 9 N.E.2d 213 (1937); Society of Good Neighbors v. Van Antwerp, 324 Mich. 22, 36 N.W.2d 308 (1949). But see The Right to Nondiscriminatory Enforcement 1134-36. The same opinions also warned that injunctive relief against discriminatory enforcement would impermissibly nullify the substantive law entirely. But see Covington v. Gausephol, $250 \mathrm{Ky} .321$, 62 S.W.2d 1040 (1933) (injunction expressly limited to bar only discriminatory enforcement). Society of Good Neighbors denied relief for the additional reason that the plaintiff, being a law violator, lacked clean hands. $C f$. New Orleans v. Levy, 233 La. 844, 98 So. $2 d 210$ (1957). But see Ashland v. Heck's, Inc., 407 S.W.2d 421, 424 (Ky. 1966).

83. United States v. Palermo, 152 F. Supp. 825 (E.D. Pa. 1957) (court ignored the allegation that defendant was singled out for tax prosecution because he was reputed to be a gangster, treating the case as a Type 11 non-invidious selective enforcement case); People v. Flanders, 140 Cal. App. 2d 765, 296 P.2d 13 (Ct. App. 1956); People v. Winters, 171 Cal. App. 2d 876, 342 P.2d 538 (App. Dep't 1959) (courts ignored allegations of discrimination-including racial discrimination-in enforcement of gambling laws, declaring that discriminatory enforcement is never a judicially-cognizable claim, except where the offense charged is malum prohibitum).

84. Creash v. State, 131 Fla. 111, 121, 179 So. 149, 153 (1938). 
and other courts have dismissed petitioners' claims on the most questionable case authority. ${ }^{85}$

However, the more offensive cases are those in which the courts, although purporting to base their decision on an insufficiency of proof, actually reject the Yick Wo doctrine as fully as the cases just discussed. In one case, ${ }^{86}$ a black owned and operated taxi company had alleged that an ordinance prohibiting the taking on of additional passengers was enforced only against itself and not against white cab companies and drivers. Affirming the lower court's refusal to enjoin prosecution for violation of that ordinance, the Illinois Supreme Court indicated that "[w] hile it is charged that white drivers have violated the ordinance, no single, specific instance is cited, nor is any company or person named." ${ }^{87}$ However, the rest of the opinion leaves no doubt that the court would have reached the same result even if specific instances had been cited and non-molested violators had been named. "Equity concerns itself only with property rights and will not intervene for the purpose of restraining the enforcement of a criminal statute . . . even though the acts of the police department may be performed in an oppressive and unlawful way." 88 Similarly, the Pennsylvania Supreme Court ${ }^{89}$ affirmed the conviction of a Democratic candidate for mayor for the use of a sound truck without a permit. After declaring that the defendant had failed to prove discriminatory enforcement, the court continued:

Even if the Salvation Army, various churches and charitable organizations did violate this ordinance therefore, such fact would not aid [the defendant] for he clearly violated this ordinarce and the [equal protection] defense . . . cannot avail [him] . . . [nor would it matter] that the police in arresting [him] and in not arresting others were improperly motivated . . ..90

There are, however, a number of cases in which courts have entertained the petitioners' allegations of discrimination. Of these, eight are procedural ${ }^{91}$ and six are decisions on the merits. ${ }^{92}$ The

85. Cone v. State, 184 Ga. 316, 324, 191 S.E. 250, 255 (1937); Bailleaux v. Gladden, 230 Ore. 606, 611, 370 P.2d 722, 724 (1962).

86. Jackie Cab Co. v. Chicago Park Dist., 366 III. 474. 9 N.E.2d 213 (1937).

87. Id. at 479,9 N.E.2d at 216.

88. Id.

89. Commonwealth v. Winfree, $408 \mathrm{~Pa}$. 128. 182 A.2d 698 (1962).

90. ld. at 139. $182 \mathrm{~A} .2 \mathrm{~d}$ at 704 .

91. People v. Gray. 254 Cal. App. 2d 256, 63 Cal. Rptr. 211 (Ct. App. 1967): Wade v. San Francisco, 82 Cal. App. 2d 337. 186 P.2d 181 (Ct. App. 1947); People v. Harris, 182 Cal. App. 2d 837, 5 Cal. Rptr. 852 (App. Depi 1960); People v. Amdur. 123 Cal. App. 2d 951. 267 P.2d 445 (App. Depi 1954): Di Maggio v. Brown. 19 N.Y.2d 283. 225 N.E.2d 871, 279 N.Y.S.2d 
procedural decisions involve determinations that particular evidence was sufficient to make out a prima facie case of discriminatory enforcement if the proferred evidence, upon retrial, supports the allegations. In one case ${ }^{93}$ the court held that even conclusory allegations of discriminatory enforcement and intent were sufficient to entitle the petitioner to an opportunity to present his proof. Although a New York decision seems to be equally sympathetic, ${ }^{94}$ the remaining six cases required a somewhat more complete allegation and offering of evidence of discriminatory enforcement and intent, and that burden being met, directed a trial on the merits.

While these cases facially give the impression that a legal remedy is finally available to persons unfairly singled out for arrest and prosecution, a closer look discloses that even in these courts the remedy may be illusory. True, the claimant is given an opportunity to present evidence in support of his claim, but he has the burden of persuasion, the quantum of proof required is a heavy one, and an essential element that must be proved is the invidious intent of enforcement officials. Nowhere in these cases can one find a reasoned explanation for placing upon a criminal defendant the burden of persuasion as to his claim of discriminatory enforcement. The closest approximation is that:

As to the conventional affirmative defenses in a criminal case, the burden is

161 (1967); People v. Walker, 14 N.Y.2d 901, 200 N.E.2d 777, 252 N.Y.S.2d 96 (1964); People v. Utica Daw's Drug Co., 16 App. Div. 2d 12, 225 N.Y.S.2d 128 (1962); People v. Solkoff, 53 Misc. 2d 137, 278 N.Y.S.2d 106 (Long Beach City Ct. 1967). Of these, all but two are determinations that a lower court erred in excluding proferred evidence supportive of a claim of discriminatory enforcement. The court in Gray reversed because the lower court had erroneously instructed the jury as to the defendant's burden of proof to establish his elaim; Solkoff is a ruling of the trial judge granting a motion for a preliminary hearing on the claim.

See also Washington v. United States, 40 I F.2d 915 (D.C. Cir. 1968) (rejecting the government's contention that prosecutorial discrimination is not subject to an equal protection claim); United Ins. Co. of Chicago v. Maloney, 127 Cal. App. 2d 155, 273 P.2d 579 (Ct. App. 1954) (reversing injunction for failure to exhaust administrative remedies, but approving in principle the equal protection claim).

92. The claim was upheld in People v. Walker, 50 Misc. 2d 751, 271 N.Y.S.2d 447 (App. T. 1966); People v. Tornatore, 46 Misc. 2d 908, 261 N.Y.S.2d 474 (Poughkeepsie City Ct. 1965); Fairlawn v. Fuller, 8 Ohio Misc. 266, 221 N.E.2d 851 (Akron Mun. Ct. 1966). The claim was rejected in Mangold Midwest Co. v. Richfield, 274 Minn. 347, 143 N.W.2d 813 (1966); People v. Paine Drug Co., 22 App. Div. 2d 156, 254 N.Y.S.2d 492 (1964), cert. denied, 382 U.S. 838 (1965); People v. Solkoff, 53 Misc. 2d 893, 280 N.Y.S.2d 455 (Long Beach City Ct. 1967).

93. Wade v. San Francisco, 82 Cal. App. 2d 337, 186 P.2d 181 (Ct. App. 1947). Wade, arrested under an ordinance prohibiting solicitation of magazine subscriptions on the sidewalk, alleging that the police, knowing of other violators, had refrained from enforcing the ordinance against them, and had enforced it against him with discriminatory intent, sought an injunction against his prosecution.

94. People v. Walker, 14 N.Y.2d 901,200 N.E.2d 777, 252 N.Y.S.2d 96 (1964). 
upon the defendant to come forward with some evidence making the defense one of the issues in the case but the burden of proof remains upon the People upon the whole case to establish the invalidity of the defenses beyond a reasonable doubt. This is the settled law as to the defense of self-defense and the defense of insanity . . . . [as to the claim of discriminatory enforccment] as a matter of sound principle, the burden should be upon the defendant, if he claims that there was intentional discrimination, to establish it by a clear preponderance of the proof. ${ }^{95}$

Nor do the cases intelligently rationalize the quantum of proof required. One court chose the "clear preponderance" standard and referred to the defendant's "heavy burden." ${ }^{96}$ Subsequent cases have either cited it without discussion, or have failed even to advert to the question. One exception is People v. Gray, ${ }^{97}$ where the sole ground for reversal was the trial court's jury instruction that the defendant had to establish discriminatory enforcement "by clear and convincing proof." Holding that the defendant's "heavy burden," properly construed, amounts to no more than a mere preponderance, the court said that to hold otherwise "is to hold that equal protection may be denied if the denial cannot be clearly and convincingly proved. We doubt that the fourteenth amendment sanctions so cynical a posture." Reasoning that access to the facts pertinent to a particular defense is a crucial consideration in allocating the burden of proof, the court suggested that it might also be considered in determining the necessary quantum. Because "[e]vidence of discriminatory enforcement usually lies buried in the consciences and files of the law enforcement agencies .... the imposition of a burden heavier than proof by a preponderance of the evidence might mean the nullification of the defense as a practical matter." ${ }^{98}$ Unfortunately the court did not pursue its reasoning further and remove the burden of persuasion from the defendant.

An examination of the cases decided on the merits justifies one's apprehensions about the unexplained and undefined burden of proof in instances of allegedly invidious selective prosecution. In Mangold Midwest Co. v. Richfield ${ }^{99}$ the Minnesota Supreme Court was unwilling to say that the trial court was clearly wrong in finding no purposeful discrimination in enforcement of a Sunday closing

95. People v. Utica Daw's Drug Co.. 16 App. Div. 2d 12. 18. 225 N.Y.S.2d 128. 134 (1962).

96. Id. at 18,225 N.Y.S.2d at 135-36.

97. 254 Cal. App. 2d 256. 63 Cal. Rptr. 211 (Ct. App. 1967).

98. Id. at 266. 63 Cal. Rptr. at 217-18.

99. 274 Minn. 347. 143 N.W.2d 813 (1966). 
ordinance. Immediately following enactment of the ordinance, the plaintiff had unsuccessfully sought a delcaratory judgment that it was unconstitutional. For more than two years Mangold stayed closed on Sundays despite the widespread violation of the ordinance by his competitors. The plaintiff then had three of its employees make Sunday purchases of restricted items from its law-violating competitors, formally informed the city of the violations, and complained of discriminatory enforcement. He then announced that since his competitors were allowed to violate the law, he too would do business on Sundays. On the following Sunday both the plaintiff and two other stores were served with complaints by the police. The fact of enforcement against the two other stores persuaded the trial court that there was no purposeful discrimination against the plaintiff, despite the testimony of the officer responsible for serving the complaints that "he had been told by his supervisor to serve a couple of other stores so that it would not look as if the village were discriminating against the plaintiffs." 100

In another Sunday closing case, a New York court, reaching an equally bizarre result, reinstated an indictment after the trial court, finding discriminatory enforcement, had dismissed the prosecution. ${ }^{101}$ The trial court had found that the city made no efforts of its own to enforce the law and that the initiative for enforcement had come wholly from the Retail Merchants Council whose complaints were directed against the defendant - a discount drug store and formidable competitor-for self-serving economic reasons rather than from a basic desire for general enforcement. ${ }^{102}$ Reversing on the basis that the Yick Wo rationale is applicable only to discrimination by public authorities, the court proclaimed that even if the Retail Merchants Council's complaints had been inspired by the basest of motives, their actions, being those of private persons, were beyond the reach of Yick Wo. The court also deduced that the competitors' motives were not solely economic, but in fact were highly moral-for they would be forced to break the law themselves if discount drug stores continued to do so, and it was this they wished to avoid. ${ }^{103}$

100. Id. at 349,143 N.W.2d at 815 .

101. People v. Paine Drug Co., 22 App. Div. 2d 156, 254 N.Y.S.2d 492 (1964), cert. denied. 382 U.S. 838 (1965).

102. People v. Painé Drug Co., 39 Misc. 2d 853, 241 N.Y.S.2d 946 (Monroe County Cl. 1963).

103. In People v. Solkoff, 53 Misc. 2d 893, 280 N.Y.S.2d 455 (Long Beach City Cl. 1967), the trial court denied the defendant's motion to dismiss the prosecution for violation of a zoning 
In three cases the claim of discriminatory enforcement prevailed. In a Sunday sales case, the trial court, after a preliminary hearing, dismissed the prosecution. ${ }^{104}$ The defendant was the operator of an independent meat market who had recently refused to negotiate a union contract; the complainant was a union official. The evidence disclosed that the union regularly sought enforcement against nonunionized markets as a means of compelling accession to a union contract. Any protestation that the union was concerned simply with obedience to the law was belied by the existence of a provision in their contracts with unionized markets requiring a special pay scale for Sunday employment! A New York appellate court reversed the conviction of a landlord for violating the housing code. ${ }^{105}$ The evidence substantiated the defendant's allegation that the prosecution had been instituted in retaliation for her exposure of corruption by housing inspectors. While there was no evidence of widespread nonenforcement against other violators, there was evidence that the time allowed her for administrative compliance was so unreasonably short as to preclude avoidance of prosecution. And, a trial court dismissed Sunday closing law prosecutions upon evidence that the city had effectively refused to prosecute anyone else but the employees of one particular store. ${ }^{106}$

\section{TYPE V: A Concluding Postscript on Low-Visibility Discrimination by Individual Policemen (H-J. Q-S).}

Type V cases are essentially similar to Type IV cases, with the additional difficulty that they involve discrimination at a much lower level of visibility. There appear to be no reported cases involving abuse of discretion to arrest by individual policemen. ${ }^{107}$

ordinance. The court was not persuaded that the defendant was the victim of discriminatory enforcement despite a concession by the city that it had no general pattern of enforcement but proceeded almost entirely on private complaints and with proof that the defendant was being prosecuted for the third time whereas other violators were virtually immune from prosecution, and had been denied the same opportunity for administrative compliance that other violators customarily receive.

104. People v. Tornatore, 46 Misc. 2d 908, 261 N.Y.S.2d 474 (Poughkeepsie City Ct. 1965).

105. People v. Walker, 50 Misc. 2d 751, 271 N.Y.S.2d 447 (App. T. 1966).

106. Fairlawn v. Fuller, 8 Ohio Misc. 266. 221 N.E.2d 851 (Akron Mun. Ct. 1966). The case is remarkable in that it is fundamentally a Type II case; but the addition of the bare allegation of intentional discrimination was held sufficient in itself to induce the court 10 infer invidiousness from non-enforcement against other violators.

107. Since the analytic focus of this article is "pure" discriminatory enforcement, its scope excludes cases in which discriminatory enforcement infringes on substantive freedoms. See, e.g.. Fowler v. Rhode Island, 345 U.S. 67 (1953): Niemotko v. Maryland, 340 U.S. 268 (1951). 
Certainly a policeman cannot be deprived of all discretion. ${ }^{108}$ The exigencies of police work are such that even the most elaborate set of statutory or regulatory directives could not succeed in removing all occasion for the exercise of judgment. The fact is, however, that far from having elaborate sets of directives, the policeman is not given even the most rudimentary guidelines. ${ }^{109}$ Instead, the policeman is free to use his discretion to oppress the poor, the Black, the culturallydeviant, and the politically-activist minorities, often with society's approval. The doctrine of Yick Wo may impose a theoretical prohibition of Type $\mathrm{V}$ discrimination, but it is the peculiar genius of our society to have both the doctrine and the discrimination. It is no historical accident that Yick Wo has been either ignored by courts or rendered useless by the overlay of need-to-prove intent and the imposition of a heavy burden of proof.

Allegations of a denial of equal protection by selective enforcement on the basis of racial prejudice, economic jealousy, or other unjustified criteria are disquieting because they involve charges of flagrant breaches of the public trust by the police. The courts, in the discharge of their public trust, should be especially diligent in ferreting out such discrimination and should, accordingly, lend a receptive ear to such defenses. First, the courts must accept the notion that discriminatory enforcement can amount to a denial of equal protection. Secondly, they must give more than lip service to their recognition by relaxing the burden of proof imposed upon the defendant. A minimum of proof should shift the burden to the state to show the absence of invidiousness. Nowhere in the selective enforcement field does the state have as great an advantage of information in its files as in Type V cases, and it, not the defendant, should be charged with the duty of producing the requisite evidence to show absence of invidiousness vel non.

108. But cf. J. Goldstein.

109. See note 17 supra. 


$$
\text { . }
$$

